\title{
PENERAPAN MODEL POE2 WE DALAM PEMBUATAN VIDEO PEMBELAJARAN FISIKA DENGAN BANTUAN APLIKASI FILMORA SEBAGAI UPAYA PENINGKATAN KEMAMPUAN KOGNITIF DAN PSIKOMOTOR SISWA
}

\author{
Haifa Hanifatun Nida ${ }^{*}$, Nana ${ }^{2}$ \\ ${ }^{1}$ Mahasiswa Program Studi Pendidikan Fisika, Universitas Siliwangi \\ ${ }^{2}$ Dosen Program Studi Pendidikan Fisika, Universitas Siliwangi \\ Tasikmalaya 46115, Jawa Barat, Indonesia \\ *E-mail: haifahanifatun@gmail.com
}

\begin{abstract}
This study aims to apply the POE2WE model in making physics learning videos with the help of the Filmora application. This research uses literature study method. By using the POE2WE model and library study method researchers can explain the advantages of physics learning videos and the Filmora application. The results of the study show that the process of delivering material between educators and students is more effective and makes the classroom atmosphere more active. Educators become easier in presenting material to students in the form of videos with the help of the Filmora application. Likewise with students who can better understand the subject matter as a form of cognitive improvement and can try to make learning videos in channeling the creativity of students as a form of psychomotor improvement.
\end{abstract}

Keywords: POE2WE Model, Learning Video, Filmora, Cognitive, Psychomotor

\begin{abstract}
Abstrak
Penelitian ini bertujuan untuk menerapkan model POE2WE dalam pembuatan video pembelajaran fisika dengan bantuan aplikasi Filmora. Penelitian ini menggunakan metode studi pustaka. Dengan menggunakan model POE2WE dan metode studi pustaka peneliti dapat memaparkan kelebihan video pembelajaran fisika serta aplikasi Filmora. Hasil dari penelitian menunjukan bahwa proses penyampaian materi antara pendidik dan peserta didik lebih efektif dan menjadikan suasana kelas lebih aktif. Pendidik menjadi lebih mudah dalam menyampaikan materi kepada peserta didik berupa video dengan bantuan aplikasi Filmora. Begitu juga dengan peserta didik yang dapat lebih memahami materi pelajaran sebagai bentuk peningkatan kognitif dan bisa mencoba membuat video pembelajaran dalam menyalurkan kreativitas peserta didik sebagai bentuk peningkatan psikomotor.
\end{abstract}

Kata kunci: Model POE2WE, Video Pembelajaran, Filmora, Kognitif, Psikomotor

\section{Pendahuluan}

Pembelajaran adalah sebuah proses komunikasi antara siswa, guru dan bahan pembelajaran. Komunikasi tidak akan berjalan tanpa bantuan sarana penyampai pesan atau media. Pesan yang akan dikomunikasikan adalah isi pembelajaran yang ada dalam kurikulum yang dituangkan oleh pengajar atau fasilitator atau sumber lain ke dalam simbol-simbol komunikasi, baik symbol verbal maupun simbol non verbal atau visual. Media pembelajaran hendaknya dipandang sebagai bagian integral dari suatu sistem pembelajaran dan bukan hanya sebagai alat bantu yang berfungsi sebagai tambahan yang digunakan bila dianggap perlu dan hanya dimanfaatkan sewaktu-waktu (Ulya, Nahdlotul : 2017).

Penggunaan media video dalam kegiatan pembelajaran dapat menarik perhatian siswa, sehingga menumbuhkan rasa ingin tahu dan termotivasi untuk belajar, dengan menggunakan media video akan berpengaruh dalam proses pelajaran dan tentunya pendidikan perlu memiliki terobosan baru yang lebih energik dalam pembelajaran karena dengan adanya media yang tepat proses pembelajaran akan mudah berjalan kemudian siswa akan lebih memahami apa yang disampaikan, sehingga materi pelajaran yang disampaikan akan diserap oleh siswa secara otomatis akan meningkatkan kempuan belajar siswa (Ulya, Nahdlotul : 2017). 
Video merupakan tayangan gambar bergerak yang disertai dengan suara. video sebagai bahan ajar noncetak kaya informasi. Video sangat lugas, jika dimanfaatkan dalam kegiatan pembelajaran, karena dapat menghadirkan informasi sampai ke hadapan siswa secara langsung. Selain itu video juga menambah dimensi baru dalam pembelajaran. Siswa lebih mudah mengingat dan memahami suatu pelajaran jika mereka tidak hanya menggunakan satu jenis indra saja, apalagi jika hanya indra pendengaran (Ulya, Nahdlotul : 2017).

Menurut Asiah, Muhamad (2018) Filmora atau lengkapnya Wondershare Filmora Video Editor adalah sebuah aplikasi atau program yang dirancang untuk membuat proses pengeditan video dengan mudah dan sederhana tapi memiliki kualitas yang cukup powerful. Saat ini banyak program editing video dengan reputasi yang tinggi dan dipakai di stasiun TV seperti Adobe Premiere atau lainnya, tapi bagi editor video pemula mungkin membutuhkan waktu yang cukup lama untuk menyelesaikan satu projek video, itu pun hasilnya belum tentu memuaskan. Wondershare Filmora Video Editing memberi solusi bagi yang ingin belajar video editing dengan waktu yang cepat, karena selain programnya yang ringan jika dibandingkan editor video lainnya, tampilan kerja filmora juga sangat sederhana dan mudah dipelajari. Meskipun tampilannya sederhana, filmora editor video tidak mengesampingkan fitur, sehingga tidak perlu khawatir dengan kualitas hasil editannya.

Menurut Nana, (2019) langkah-langkah pembelajaran model POE2WE yaitu: 1) Prediction (Prediksi) yaitu peserta didik membuat prediksi atau dugaan awal terhadap suatu permasalahan. 2) Observation (observasi) yaitu membuktikan prediksi yang telah di buat oleh peserta didik. Peserta didik diajak melakukan eksperimen berkaitan dengan masalah atau persoalan yang ditemukan. 3) Explanation (Eksplanasi atau menjelaskan) yaitu peserta didik memberikan penjelasan terhadap hasil eksperimen yang telah dilakukan. 4) Elaboration (Elaborasi) yaitu peserta didik membuat contoh atau menerapkan konsep dalam kehidupan sehari-hari. 5) Write (menulis) yaitu melakukan komunikasi secara tertulis, merefleksikan pengetahuan dan gagasan yang dimiliki peserta didik. 6) Evaluation (evaluasi) yaitu evaluasi terhadap pengetahuan, keterampilan, dan perubahan proses berfikir peserta didik.

\section{Metode Penelitian}

Penelitian ini menggunakan metode studi pustaka berupa data teoretis dan memperhatikan aspek kualitatif. Artinya penulis mengambil data melalui literatur yang sesuai dengan penelitian yang dilakukan,

\section{Hasil dan Pembahasan}

Menurut Nana, (2018) Model pembelajaran Prediction, Observation, Explanation, Elaboration, Write dan Evaluation (POE2WE) merupakan model pembelajaran yang dikembangkan untuk mengetahui pemahaman siswa mengenai suatu konsep dengan 
pendekatan konstruktivistik. Model ini membangaun pengetahuan dengan urutan proses terlebih dahulu meramalkan atau memprediksi solusi dari permasalahan, melakukan eksperimen untuk membuktikan prediksi, kemudian menjelaskan hasil eksperimen yang diperoleh secara lisan maupun tertulis, membuat contoh penerapan dalam kehidupan seharihari, menuliskan hasil diskusi dan membuat evaluasi tentang pemahaman siswa baik secara lisan maupun tertulis. Model pembelajaran POE2WE dapat menjadikan siswa sebagai subjek di dalam pembelajaran. Siswa aktif dalam menemukan suatu konsep melalui pengamatan atau eksperimen secara langsung, bukan dari menghafal buku materi maupun penjelasan dari guru. Model ini memungkinkan siswa aktif dalam proses pembelajaran, memberikan kesempatan kepada siswa untuk mengkonstrukssi pengetahuannya, mengkomunikasikan pemikirannya dan menuliskan hasil diskusinya sehingga siswa lebih menguasai dan memahami konsep yang akan berdampak pada peningkatan prestasi belajar siswa.

Menurut Nana, (2018) langkah-langkah pembelajaran model POE2WE secara terinci sebagai berikut:

a) Prediction

Tahap prediction yaitu siswa membuat prediksi atau dugaan awal terhadap suatu permasalahan. Guru mengajukan pertanyaan yang dapat mendorong siswa untuk dapat membuat prediksi atau jawaban sementara dari suatu permasalahan.

\section{b) Observation}

Tahap Observation yaitu untuk membuktikan prediksi yang telah di buat oleh siswa. Siswa diajak melakukan eksperimen berkaitan dengan masalah atau persoalan yang di temukan. Selanjutnya siswa mengamati apa yang terjadi, kemudian siswa menguji kebenaran dari dugaan sementara yang telah dibuat. Tahap Observation pada model POEW identik dengan fase Exploration pada pendekatan konstruktivistik.

\section{c) Explanation}

Tahap Explanation atau menjelaskan yaitu siswa memberikan penjelasan terhadap hasil eksperimen yang telah dilakukan. Penjelasan dari siswa dilakukan melalui diskusi dengan anggota kelompok kemudian tiap kelompok mempresentasikan hasil diskusinya di depan kelas. Jika prediksi yang di buat siswa ternyata terjadi di dalam eksperimen, maka guru membimbing siswa merangkum dan memberi penjelasan untuk menguatkan hasil eksperimen yang dilakukan. Namun jika prediksi siswa tidak terjadi dalam eksperimen, maka guru membantu siswa mencari penjelasan mengapa prediksi atau dugaannya tidak benar. Tahap explanation identik dengan fase explanation pada pendekatan konstuktivistik.

\section{d) Elaboration}

Tahap elaboration yaitu siswa membuat contoh atau menerapkan konsep dalam kehidupan sehari-hari. Tahap elaboration di ambil dari pendekatan konstruktivistik. Tahap ini guru medorong siswa untuk menerapkan konsep baru dalam situasi baru sehingga siswa lebih 
memahami konsep yang di ajarkan guru. Tahap ini pengembangan dari pendekatan konstruktivistik.

e) Write

Tahap write atau menulis yaitu melakukan komunikasi secara tertulis, merefleksikan pengetahuan dan gagasan yang dimiliki siswa.

\section{f) Evaluation}

Tahap Evaluation yaitu evaluasi terhadap pengetahuan, keterampilan dan perubahan proses berfikir siswa.

Penerapan model POE2WE dalam pembuatan video pembelajaran fisika dengan bantuan aplikasi Filmpra ini dimaksudkan sebagai upaya dalam meningkatkan kemampuan kognitif dan kemampuan psikomotor siswa.

Menurut Arfianti, (2018) faktor kognitif mempunyai peranan penting bagi keberhasilan anak dalam belajar karena sebagian besar aktivitas dalam belajar selalu berhubungan dengan masalah mengingat dan berpikir. Kemampuan kognitif dimaksudkan agar anak mampu melakukan eksplorasi terhadap dunia sekitar melalui panca inderanya sehingga dengan pengetahuan yang didapatkannya tersebut anak dapat melangsungkan hidupnya.

Menurut Zarhadi, (2013) psikomotor merupakan aspek yang berkaitan dengan keterampilan (skill) atau kemampuan bertindak setelah seseorang menerima pengalaman belajar tertentu. Hasil belajar psikomotor ini sebenarnya merupakan kelanjutan dari hasil belajar kognitif (memahami sesuatu) dan hasil belajar afektif (yang baru tampak dalam bentuk kecenderungan-kecenderungan berperilaku). Hasil belajar keterampilan (psikomotor) dapat diukur melalui:(1) pengamatan langsung dan penilaian tingkah laku peserta didik selama proses pembelajaran praktik berlangsung, (2) sesudah mengikuti pembelajaran, yaitu dengan jalan memberikan tes kepada peserta didik untuk mengukur pengetahuan, keterampilan, dan sikap, (3) beberapa waktu sesudah pembelajaran selesai dan kelak dalam lingkungan kerjanya.

Pendidikan memiliki peran penting dalam mencerdaskan kehidupan bangsa. Guru sebagai pelaku utama proses pendidikan men-jadi salah satu penentu terciptanya pendidikan yang berkualitas. Beberapa peran guru yakni sebagai pendidik, pengajar, fasilitator, dan inovator. Dalam menjalankan perannya, guru dituntut untuk mampu memilih metode serta merancang kegiatan pembelajaran yang meng-aktifkan siswa, menyediakan sumber belajar yang variatif, dan memilih media pembelajaran yang memungkinkan siswa mudah dalam menyerap informasi serta mampu menumbuhkan motivasi belajar siswa. Motivasi menjadi hal penting dalam me-lakukan suatu kegiatan, khususnya dalam pem-belajaran. Motivasi harus 
terus ditumbuhkan dalam diri siswa sebagai modal dasar untuk mecapai tujuan belajarnya. Seorang guru harus mau berinovasi dalam setiap pembelajaran guna menumbuhkan motivasi belajar siswa. Motivasi akan mampu memberikan kekuatan tersendiri bagi siswa (Suryansyah, Titi dan Suwarjo, 2016). Motivasi belajar bisa dikatakan sebagai suatu proses yang memberi semangat, arah, dan kegigihan perilaku (Santrock, 2011).

Menurut Suryansyah, Titi dan Suwarjo, (2016) penggunaan media diharapkan dapat mengoptimalkan kegiatan pembelajaran. Kemenarikan dari suatu media mampu menjadi daya tarik dari media itu sendiri. Pemanfaatan media dalam belajar dapat membantu meningkatkan konsentrasi siswa. Guru bisa menggunakan jenis media audio visual yang mampu memberikan kejelasan terhadap suatu materi yang dipelajari. Jenis media audio visual bisa berupa video pembelajaran. Pengambilan objek dalam video bisa disesuaikan dengan karakteristik siswa. Banyak kelebihan pemanfaatan video dalam pembelajaran, salah satunya seperti yang disampaikan oleh Bavarharji, Alavi, dan Letchumanan (2014) bahwa "The results showed that the effects of viewing captioned instructional videos are greater on vocabulary acquisition and language proficiency develop-ment than on content comprehension". Dari pernyataan tersebut dapat dinyatakan bahwa pemanfaatan video dapat meningkatkan kemampuan bahasa siswa. Dari penguasaan bahasa yang meningkat tentu akan mempermudah siswa dalam memahami materi yang disampaikan.

Filmora atau lengkapnya Wondershare Filmora Video Editor adalah sebuah aplikasi atau program yang dirancang untuk membuat proses pengeditan video dengan mudah dan sederhana tapi memiliki kualitas yang cukup powerful. Saat ini banyak program editing video dengan reputasi yang tinggi dan dipakai di stasiun TV seperti Adobe Premiere atau lainnya, tapi bagi editor video pemula mungkin membutuhkan waktu yang cukup lama untuk menyelesaikan satu projek video, itu pun hasilnya belum tentu memuaskan. Wondershare Filmora Video Editing memberi solusi bagi yang ingin belajar video editing dengan waktu yang cepat, karena selain programnya yang ringan jika dibandingkan editor video lainnya, tampilan kerja filmora juga sangat sederhana dan mudah dipelajari. Meskipun tampilannya sederhana, filmora editor video tidak mengesampingkan fitur, sehingga tidak perlu khawatir dengan kualitas hasil editannya (Asiah, Muhamad : 2018).

\section{Kesimpulan}

Berdasarkan hasil penelitian di atas, dapat disimpulkan bahwa dengan menerapkan model POE2WE dalam pembuatan video pembelajaran fisika dengan bantuan aplikasi Filmora proses penyampaian materi antara pendidik dan peserta didik lebih efektif dan menjadikan suasana kelas lebih aktif. Pendidik menjadi lebih mudah dalam menyampaikan materi kepada peserta didik berupa video dengan bantuan aplikasi Filmora. Begitu juga dengan peserta didik yang dapat lebih memahami materi pelajaran sebagai bentuk 
peningkatan kognitif dan bisa mencoba membuat video pembelajaran dalam menyalurkan kreativitas peserta didik sebagai bentuk peningkatan psikomotor.

\section{Ucapan Terima Kasih}

Penulis mengucapkan terima kasih kepada Dr. Nana, M.Pd selaku dosen Jurusan Pendidikan Fisika Universitas Siliwangi yang telah membimbing dalam pembuatan jurnal ini.

\section{Referensi}

Arfianti, YA. (2018). Kemampuan Kognitif. [Online]. Tersedia: http://repo.iaintulungagung.ac.id/8838/5/BAB\%20II.pdf [18 Februari 2020]

Asiah, Muhamad. (2018). Mengenal Filmora, Aplikasi Video Editing yang Ringan dan Powerfu.[Online]. Tersedia: https://www.luwungdesain.com/2018/03/mengenalfilmora-aplikasi-video-editing.html [18 Februari 2020]

Bavaharji, M., Alavi, Z. K., \& Letchumanan, K. (2014). Captioned instructional video: effects on content comprehension vocabulary acquisition and language proficiency. Canadian Center of Science and Education, 7, 1-16

Nana. (2018). Model Prediction, Observation, Explanation, Elaboration, Write, and Evaluation (POE2WE) Alternatif Pembelajaran Fisika di Era Revolusi Industri 4.0. Jurnal Pendidikan Fisika FKIP Universitas Siliwangi.

Nana. (2019). Pengembangan Inovasi Pembelajaran Digital Menggunakan Model Blended POE2WE di Era Revolusi Industri 4.0. [Online]. Tersedia: https://jurnal.uns.ac.id/prosidingsnfa/article/view/35915 [18 Februari 2020]

Santrock, J. W. (2011). Psikologi pendidikan. Jakarta : Kencana

Suryansyah, Titi dan Suwarjo. (2016). Pengembangan Video Pembelajaran untuk Meningkatkan Motivasi Hasil Belajar Kognitif Siswa Kelas IV SD. [Online]. Tersedia: http://journal.uny.ac.id/index.php/jpe [18 Februari 2020]

Ulya, Nahdlotul. (2017). Pengembangan Media Video Pembelajaran Pada Materi Gempa Bumi Di SMP Negeri 3 Manisrenggo Kabupaten Klaten. Skripsi, FKIP: UMS

Zarhadi. (2013). Definisi Kognitif, Afektif, dan Psikomotorik. [Online]. Tersedia: http://adidilib88.blogspot.com/2013/09/definisi-kognitif-afektif-dan.html

Februari 2020] 